\title{
Rainwater Harvesting System in a Congested Residential Estate
}

\author{
Evon E.W. Tang ${ }^{1}$ and Darrien Y.S. Mah ${ }^{2}$ \\ ${ }^{1,2}$ Department of Civil Engineering, Faculty of Engineering, Universiti Malaysia Sarawak, \\ Kuching, Sarawak, Malaysia. \\ ${ }^{1}$ Email: evontangeewen@gmail.com, 22Email: ysmah@feng.unimas.my
}

\begin{abstract}
Occurrences of flash floods in urban areas have increased significantly and become an issue of concern to the public. However, physical development continues unabated due to urbanisation and high demands for residential houses. Towards this end, a Water Sensitive Urban Design (WSUD) approach such as rainwater harvesting system is proposed for residential development to mitigate flash floods without discouraging economic development of a city. Conventional rainwater tank is not suitable anymore as most of the residential housing developments are providing smaller land space. Thus, a design to cater for limited empty spaces is emerging. This has been the intension of this paper to introduce a wall-mount rainwater harvesting system in congested residential estates. In this research, super slim rainwater tank and air conditioner-sized tank have been designed to fit into a standard housing compound. The rainwater tanks act as a tool to store certain amount of stormwater runoff from roof area before it is discharged into drainage system. It is found that the peak runoff discharge is reduced from $0.003100 \mathrm{~m}^{3} / \mathrm{s}$ to $0.002703 \mathrm{~m}^{3} / \mathrm{s}$ and $0.002152 \mathrm{~m}^{3} / \mathrm{s}$ for the two types of aforementioned tanks. Reductions of $13 \%$ and $31 \%$ on peak runoff discharge are registered respectively by testing different configuration of water tanks. Due to the reduction of peak runoff discharge, the stormwater runoff could be controlled and subsequently mitigate the occurrence of flash flood. Sustainability could be achieved by managing stormwater runoff in an effective way with the aids of rainwater harvesting system.
\end{abstract}

Keywords: Rainwater Harvesting, Detention, Flash flood, Stormwater runoff, Urban drainage, Water Sensitive Urban Design.

\section{Introduction}

Due to the rapid economic growth and fast urban development of Kota Samarahan area, the local population has risen substantially. Consequently, natural hydrological cycle and catchment's hydraulic characteristics have suffered significant changes. Construction of infrastructures has caused changes in land use patterns in many places [1]. As such, the peak runoff discharge increases as runoff is hindered from infiltrating into the soil; instead, the water flows into drains [2]. The conventional drainage system is no longer effective in managing the increased runoff. Hence, flash floods occur frequently and the problem might worsen particularly in the downstream areas [3].

This research focuses on the implementation of a Water Sensitive Urban Design (WSUD) approach [4]-[7] which is a rainwater harvesting system [8]-[13] in a congested residential area of Kota Samarahan. Due to the high demand for housing, most of the residential developments have higher density of built-up units. Houses are designed with limited empty spaces [14]. Figure 1 shows an aerial map depicting the development of residential estates surrounding Universiti Malaysia

Manuscript History:

Received 3 June, 2015, Revised 27 July, 2015, Accepted 13 August, 2015, Published 30 September, 2015

e-ISSN 2289-7771

Copyright $\odot 2015$ JASPE 
Sarawak. Houses are tightly packed together. Conventional rainwater tanks which usually require large land space are no longer suitable. Therefore, wall-mount rainwater harvesting system is introduced here for such residential estates with limited space. Since the research is carried out in a residential area, the water collected is intended for toilet flushing, washing and gardening. As the water is expected to be used up rapidly, the water tank would be in empty condition most of the time; thus it is able to detain sufficient runoff volume and control the stormwater runoff in the surrounding area.

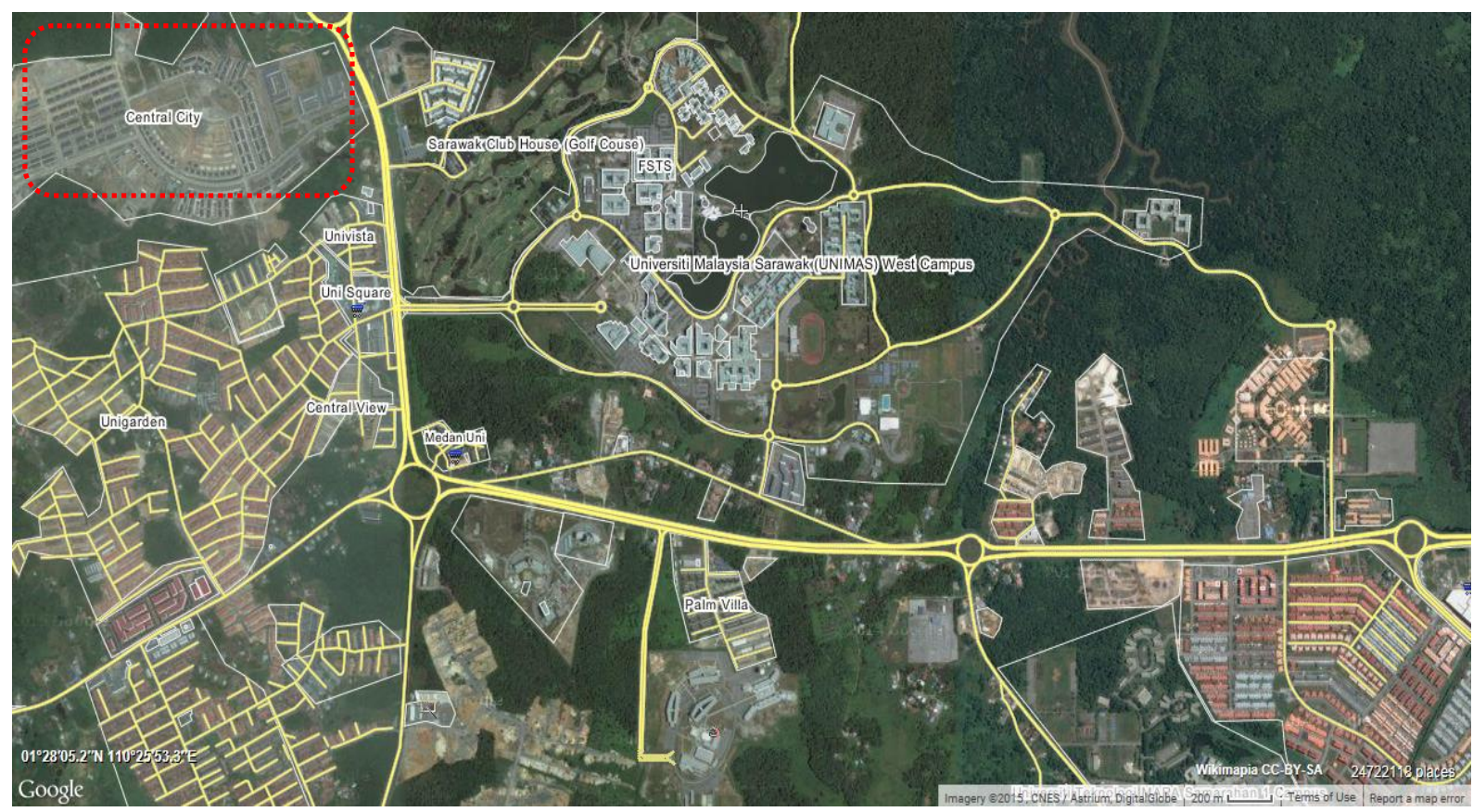

Figure 1. Development of residential estates surrounding Universiti Malaysia Sarawak, with the selected study area - Central City housing estate (http://wikimapia.org)

The study area of this research is Central City housing estate, Kota Samarahan. The housing estate is adjacent to the Kuching Samarahan Expressway; it consists of 2,141 units of residential houses as well as commercial properties. Due to the general market condition and limited land availability for housing development, it is found that property developers prefer to build typical terrace houses in order to meet the high demand of housing. Hence, an intermediate double-storey terrace house has been chosen for this research.

\section{Motivation}

A rainwater tank acts as a tool to store a certain amount stormwater runoff from a roof catchment area before it is discharged into the drain. Hence, it helps reduce peak runoff discharge. Wall-mount rainwater tank was recently introduced in Malaysia and is still a fairly new product to most local people. Hence, the suitable size of rainwater tank for the local housing estates needs to be investigated. There are two types of rainwater tank designs proposed in this research, which are: 1) super slim water tank, and 2) air conditioner-sized water tanks with interconnecting arrangement. These water tanks are specially-designed for small space as it can be attached to a wall, placed in utilised the space as well as fitted in alignment in a congested housing development.

In this research, the sizes of water tanks are designed based on the rainfall characteristics and their demand in Kota Samarahan. The runoff volume detained is determined based on catchment area to investigate the effectiveness of the rainwater harvesting system. For comparison, the smallest size 
Table 1. Comparison of rainwater tanks

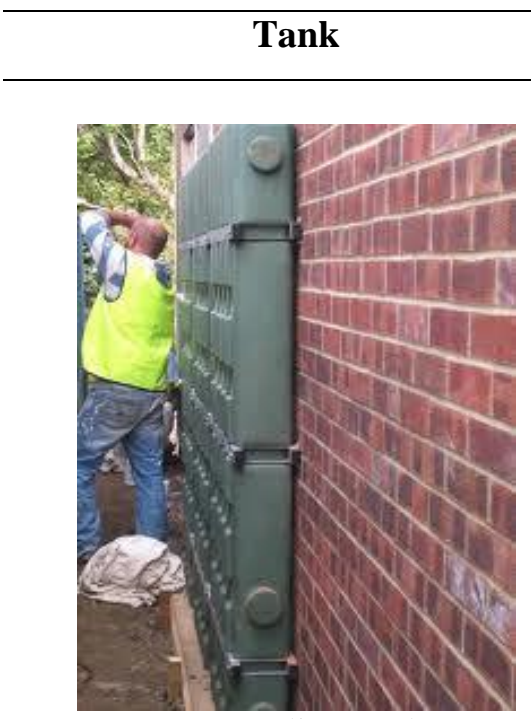

Super Slim Tank

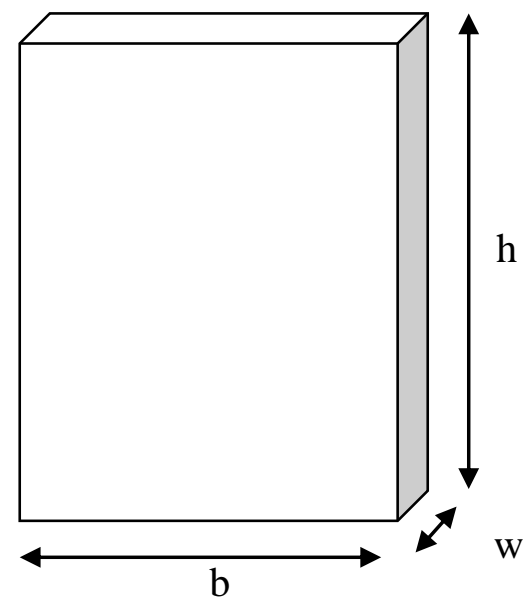

$\mathrm{h}=1800 \mathrm{~mm}$

$\mathrm{w}=240 \mathrm{~mm}$

$\mathrm{b}=1200 \mathrm{~mm}$

Volume $=$

$0.501 \mathrm{~m}^{3}$ $\mathrm{h}=700 \mathrm{~mm}$

$\mathrm{w}=240 \mathrm{~mm}$

$\mathrm{b}=850 \mathrm{~mm}$

\section{Volume}

1 tank $=0.143 \mathrm{~m}^{3}$

5 tanks $=0.715 \mathrm{~m}^{3}$

Air Conditioner-Sized Tank
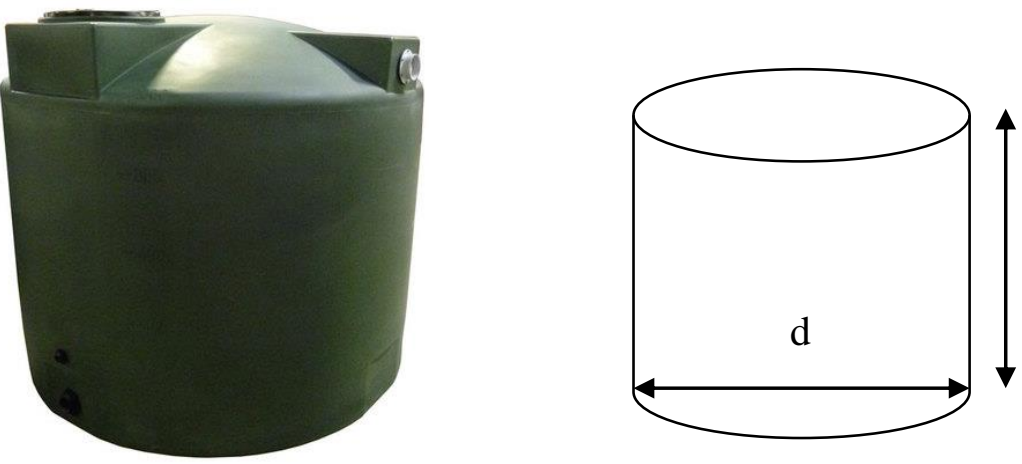

$$
\begin{aligned}
\mathrm{d} & =41 ', \\
& =1041 \mathrm{~mm} \\
\mathrm{~h} & =41^{\prime}, \\
& =1041 \mathrm{~mm}
\end{aligned}
$$

$\mathrm{h}$

Volume $=$

$0.884 \mathrm{~m}^{3}$ 
of conventional rainwater tank, super slim water tank and air conditioner-sized water tank are tabulated in Table 1 to illustrate the amount of space required.

Super slim rainwater tanks are aesthetic, economical as well space-saving. On the other hand, air conditioner-sized water tanks are also proposed in order to meet local residential requirements. However, the effect of individual air conditioner-sized water tank is not significant; several similar air conditioner-sized water tanks have been introduced in this research to optimise the rainwater harvesting system. The conventional rainwater tanks available in the local market are mostly in circular shape and always come with sizes ranging from 160 to 880 gallons (605 to 3331 litres).

The conventional tank size is almost twice the size of super slim tank. Hence wall-mount rainwater tanks are more suitable for congested development schemes; the tank can fit into the compound of a standard intermediate double-storey terrace house.

\section{Methods}

In order to determine the workability of rainwater harvesting system, computer simulations have been carried out using the Storm Water Management Model Version 5 (SWMM 5.0) [15]-[18]. Some procedures are required in order to minimise error inputs into the modelling, which are outlined below:

a) Suitable storm duration is selected;

b) Appropriate roof catchment is determined;

c) Suitable tank size is designed to fit into housing area;

d) Appropriate hydrological simulation is generated; and

e) Hand calculation is carried out based on Rational Equation to verify simulation results.

In order to start the SWMM simulation, first, a site plan of the study site should be loaded into SWMM environment (see Figure 2). The site plan, saved in BMP format, is loaded using View $>$ Backdrop $>$ Load. The flow unit should be set as CMS, and the dimension is set in metres. Other units used in SWMM should be consistent and same as requested in the system throughout modelling.

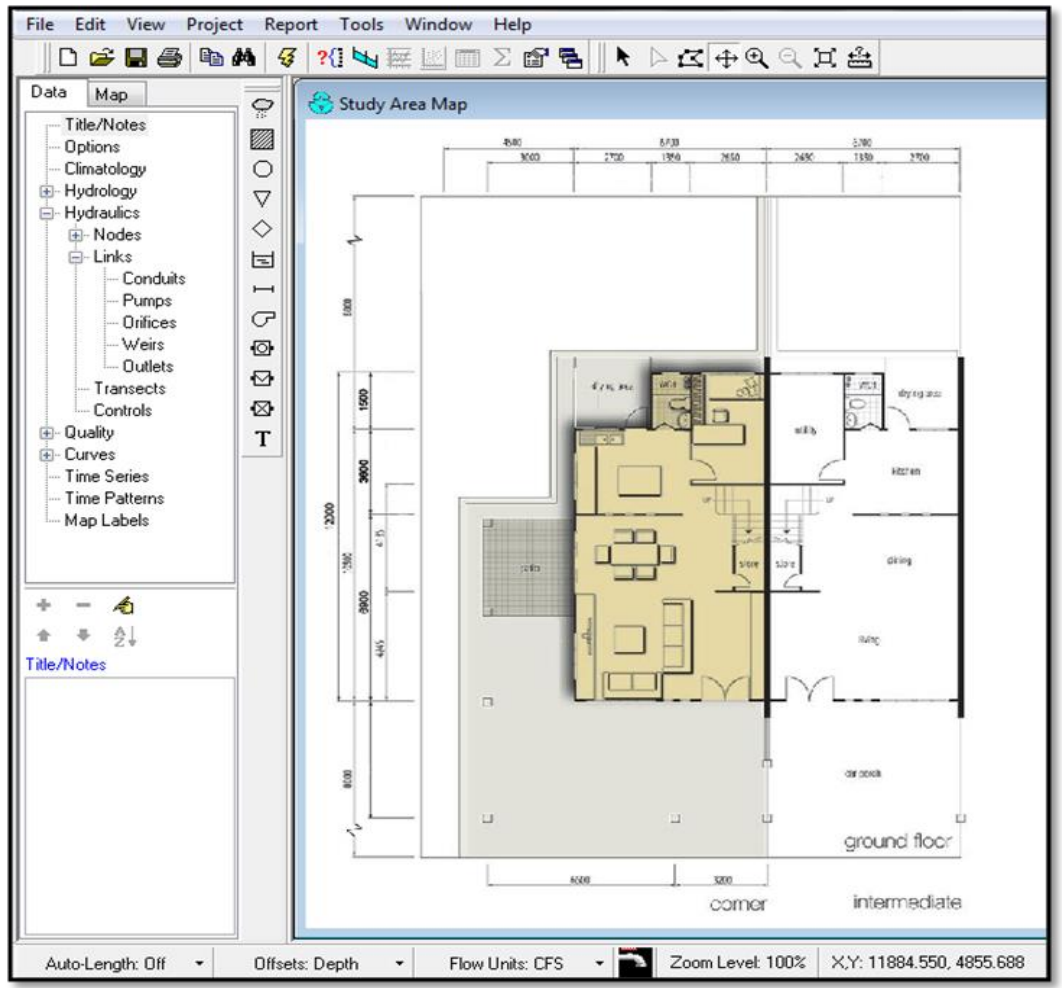

Figure 2. Backdrop of the site plan in Central City 
Next, a rain gauge, displayed as icon, 9 is inserted. It represents the design rainfall in modelling. Related data such as calculated rainfall intensity, rainfall format are entered into the rain gauge column. Besides that, there is a time series section, where name, rainfall and storm duration are required to be filled into 'time series editor' column. Figure 3 shows the rain gauge column and time series editor.
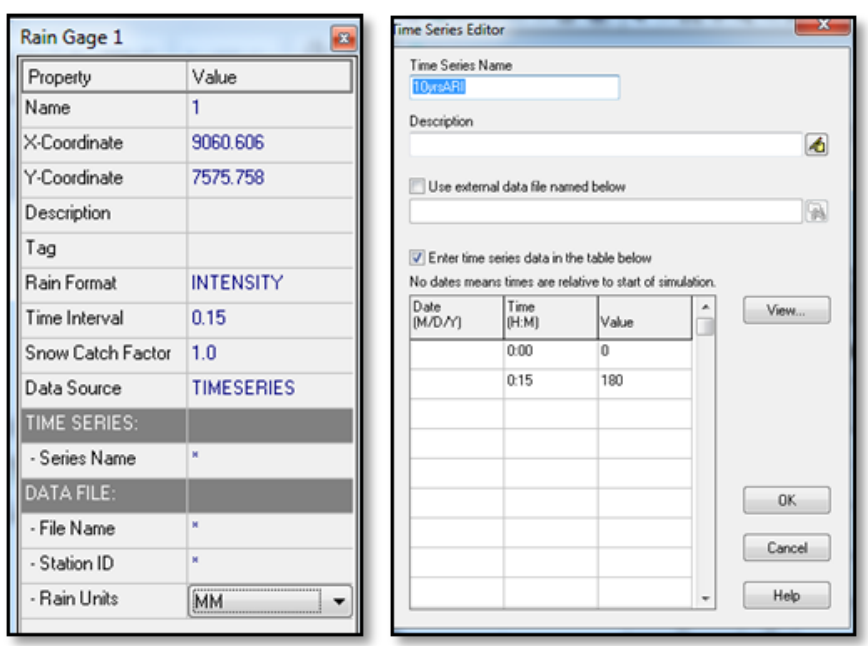

Figure 3. Rain gauge column and time series editor

After that, roof catchment is sketched out using icon . As this research is tested on a unit of intermediate terrace house, a small roof catchment is drawn on the site plan. The drawn area is shaded for clearer view. Details of sub-catchment such as area, width, percentage of slope and other parameters are filled in 'sub-catchment editor' column.

The next step is to add junctions and conduits into the map in suitable positions. Junction acts as a node to connect links and sub-catchment. It is represented by $\mathrm{O}$. Conduit is a form of conveyance to discharge stormwater from a node to another. It is represented by $\mapsto$. Parameters needed are input into the editor as well.

Lastly, a storage unit, shown as $\mathrm{E}$ is inserted at a suitable place where the stormwater runoff is to be discharged into that point. It acts as the rainwater tank. All the detailed information and properties such as invert elevation, area and depth of rainwater tank are proposed, calculated and input into 'storage unit's editor'. Figures 4 and 5 show the storage unit editor and model view of the developed SWMM model respectively. 


\begin{tabular}{|c|c|c|c|c|}
\hline \multicolumn{2}{|l|}{ Storage Unit 3} & \multicolumn{3}{|l|}{ Subcatchment 1} \\
\hline $\mid \begin{array}{l}\text { Property } \\
\end{array}$ & Value & \begin{tabular}{|l|l|} 
Property \\
\end{tabular} & Value & \\
\hline & & X-Coordinate & 7191.919 & a \\
\hline Name & 3 & Y-Coordinate & 5191.920 & \\
\hline X-Coordinate & 8421.053 & Description & & \\
\hline Y.Coordinate & 2937.182 & Tag & & \\
\hline Description & & Rain Gage & 1 & \\
\hline Tag & & Outlet & 2 & \\
\hline & & Area & 0.008874 & \\
\hline Inflows & NO & Width & 0.11 & \\
\hline Treatment & NO & \% Slope & 0.2 & \\
\hline Invert El. & 0.6 & $\%$ Imperv & 80 & \\
\hline Max. Depth & 1.2 & N-Imperv & 0.01 & \\
\hline & & N.Perv & 0.1 & \\
\hline | Initial Depth & 0 & Dstore-Imperv & 0.05 & \\
\hline Ponded Area & 0.144 & Dstore-Perv & 0.05 & \\
\hline Evap. Factor & 0 & Zero-Imperv & 25 & \\
\hline Infiltration & NO & Subarea Routing & OUTLET & \\
\hline & NO & Percent Routed & 100 & \\
\hline Storage Curve & TABULAR & Infiltration & HORTON & \\
\hline
\end{tabular}

Figure 4. Storage unit and sub-catchment column

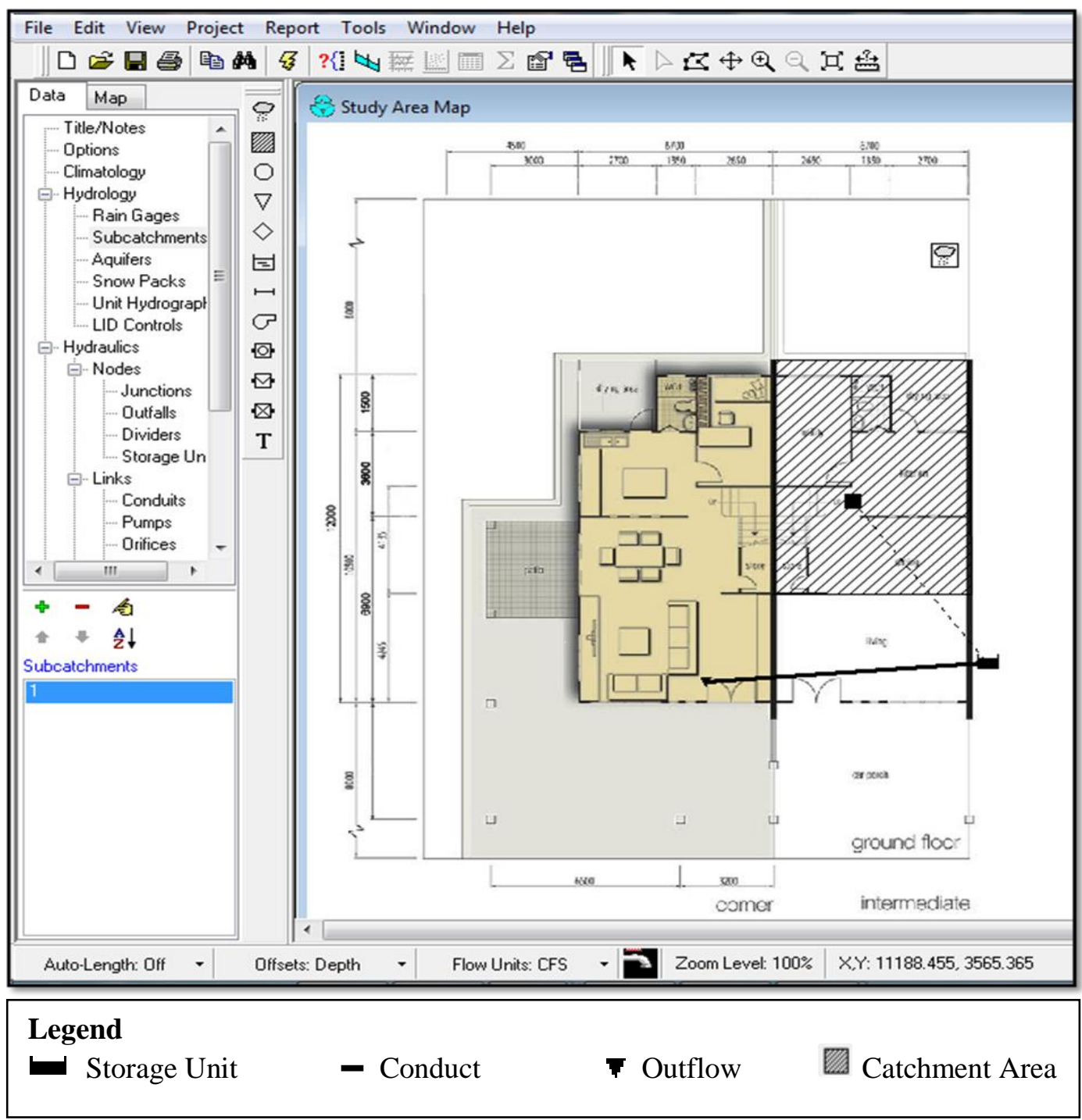

Figure 5. View of developed SWMM model 


\section{Results and Discussion}

Three scenarios are carried out in order to investigate the effectiveness of rainwater harvesting system. The scenarios are listed in Table 2. Different configuration of water tanks for Scenarios 2 and 3 , which are able to fit into a congested housing area have been proposed as depicted in Figure 6 . These arrangements of water tanks are used to generate simulation. Storm events of 10 -year ARI with duration of 15 minutes have been chosen as the Design Storm. It is estimated at $0.0031 \mathrm{~m}^{3} / \mathrm{s}$, which is the most intense stormwater runoff out of a small roof catchment of a single house. The estimated roof catchment area is $62 \mathrm{~m}^{2}$. Figure 7 shows the results of simulation.

Table 2. Summary of scenarios

\begin{tabular}{|c|l|c|c|}
\hline Scenario & \multicolumn{1}{|c|}{ Condition } & Dimension (mm) & $\begin{array}{c}\text { Volume } \\
\text { detained } \\
\text { (Litres) }\end{array}$ \\
\hline Scenario 1 & $\begin{array}{l}\text { Existing condition (without } \\
\text { rainwater tank) }\end{array}$ & - & - \\
\hline Scenario 2 & $\begin{array}{l}\text { Single super slim wall-mounted } \\
\text { rainwater tank }\end{array}$ & $1800 \times 1200 \times 240$ & 500 \\
\hline Scenario 3 & $\begin{array}{l}\text { Five air conditioner-sized wall- } \\
\text { mounted rainwater tanks }\end{array}$ & $700 \times 850 \times 240$ & 714 \\
\hline
\end{tabular}

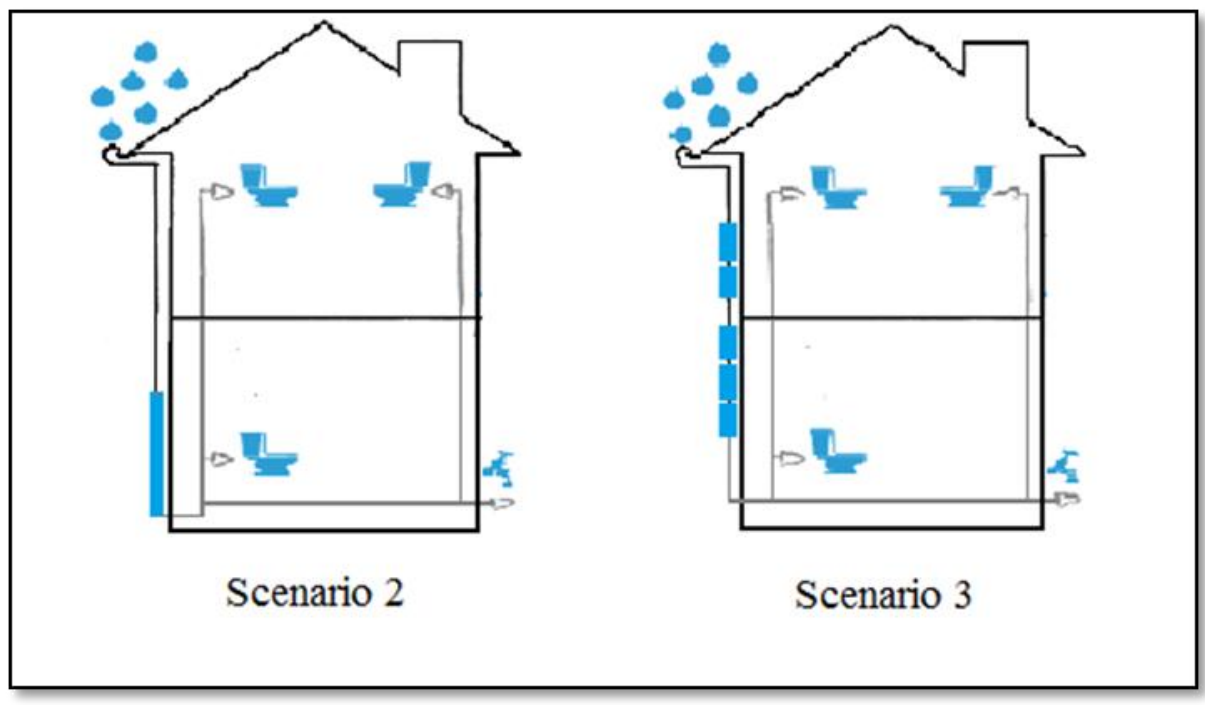

Figure 6. View of arrangement of tanks in Scenarios 2 and 3 


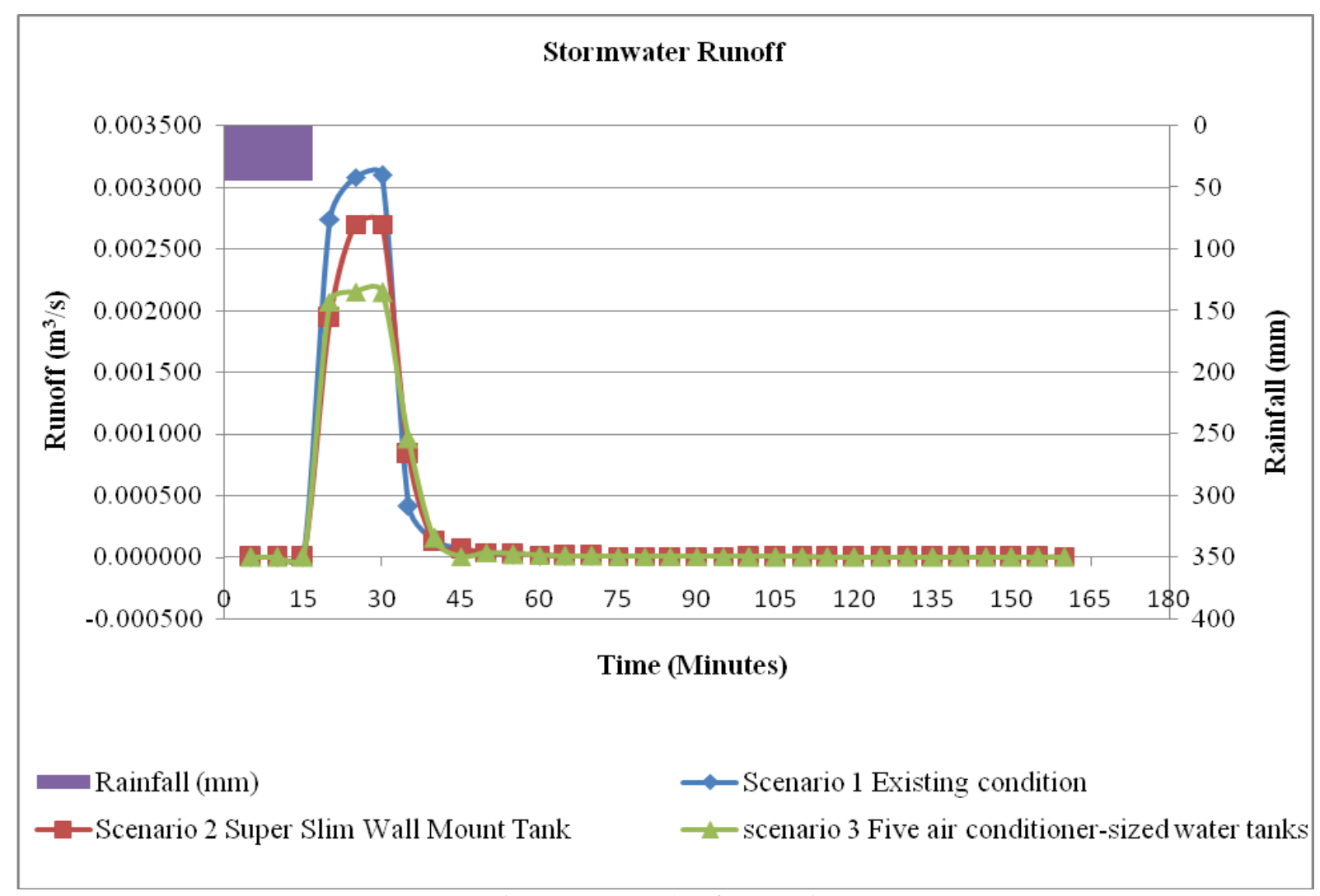

Figure 7. Result of scenarios

Based on the results, it shows that with the presence of rainwater tanks, the existing peak runoff discharge of $0.003100 \mathrm{~m}^{3} / \mathrm{s}$ is reduced to $0.002703 \mathrm{~m}^{3} / \mathrm{s}$ (which is a reduction of $13 \%$ ) and $0.002152 \mathrm{~m}^{3} / \mathrm{s}$ (a reduction of 31\%) in Scenarios 2 and 3 respectively. Reductions of $13 \%$ and $31 \%$ on peak runoff discharge are encouraging enough to lower the possibility of flooding as it reduces the burden of conventional drainage. Besides, the effect of a single house is small, but the cumulative effect is great. Higher volume of runoff over the whole residential estate could be trapped and utilised, hence reducing peak runoff more effectively. The configuration of water tank should be designed to fit into limited boundary so as not to affect aesthetic view of the houses as well as the optimum design based on rainfall data; this is to avoid wastage.

\section{Conclusion}

A computer model of implementing the rainwater harvesting system in congested residential estate at Central City, Kota Samarahan has been carried out successfully. Large water tanks are not suitable in a congested area, but this can be solved using different configuration of wall-mount rainwater tanks, as proven in this research project. In conclusion, implementation of rainwater harvesting system in a congested residential estate in the future is highly recommended for two reasons: it is able to control stormwater runoff to a lower peak discharge; and it can mitigate flash floods. Sustainable development could be achieved by installing rainwater harvesting systems.

\section{Acknowledgement}

The authors wish to acknowledge the Faculty of Engineering, Universiti Malaysia Sarawak for the opportunity and support to accomplish the research project. 


\section{References}

[1] Zakaria, N.A., Ab Ghani, A., Abdullah, R., Sidek, L.M., Kassim, A.H., and Ainan, A. (2004). MSMA - a new urban stormwater management manual for Malaysia. $6^{\text {th }}$ International Conference on Hydroscience and Engineering (ICHE-2004), May 30 - June 3, Brisbane, Australia.

[2] Pizzuto, J.E., Hession, W.C., and McBride, M. (2000). Comparing gravel-bed rivers in paired urban and rural catchments of southeastern Pennsylvania. Geology, 28(1), 79-82.

[3] Borneo Post Online (2011). Flood makes village road impassable. Available on http://www.theborneopost.com/2011/12/27/flood-makes-village-road-impassable/ [Accessed on 17th October 2014]

[4] Sieker, H., and Klein, M. (1998). Best management practices for stormwater-runoff with alternative methods in a large urban catchment in Berlin, Germany. Water Science and Technology, 38(10), 91-97.

[5] Coombes, P.J., Argue, J.R., and Kuczera, G. (2000). Figtree Place: a case study in Water Sensitive Urban Development (WSUD). Urban Water, 1(4), 335-343.

[6] Foley, B.A., and Daniell, T.M. (2004). The role of WSUD in improving the sustainability of urban developments. International Conference on Water Sensitive Urban Design (WSUD2004), Adelaide, Australia.

[7] Beecham, S., and Chowdhury, R. (2012). Effects of changing rainfall patterns on WSUD in Australia. Proceedings of the ICE-Water Management, 165(5), 285-298.

[8] Chilton, J.C., Maidment, G.G., Marriott, D., Francis, A., \& Tobias, G. (2000). Case study of a rainwater recovery system in a commercial building with a large roof. Urban Water, 1(4), 345-354.

[9] Che-Ani, A.I., Shaari, N., Sairi, A., Zain, M.F.M., and Tahir, M.M. (2009). Rainwater harvesting as an alternative water supply in the future. European Journal of Scientific Research, 34(1), 132-140.

[10] Chiu, Y.R., Liaw, C.H., and Chen, L.C. (2009). Optimizing rainwater harvesting systems as an innovative approach to saving energy in hilly communities. Renewable Energy, 34(3), 492-498.

[11] Eroksuz, E., and Rahman, A. (2010). Rainwater tanks in multi-unit buildings: a case study for three Australian cities. Resources, Conservation and Recycling, 54(12), 1449-1452.

[12] Imteaz, M.A., Shanableh, A., Rahman, A., and Ahsan, A. (2011). Optimisation of rainwater tank design from large roofs: a case study in Melbourne, Australia. Resources, Conservation and Recycling, 55(11), 1022-1029.

[13] Brodie, I. (2012). Stormwater harvesting and WSUD frequent flow management: a compatibility analysis. Water Science \& Technology, 66(3), 612-619.

[14] Mah, D.Y.S., bin Mohamad Salehe, A.H., and Putuhena, F.J. (2014). Water Sensitive Urban Design in existing urban settings: case study of dry detention pond in Kuching City. In InCIEC 2013, 315-322, Springer Singapore.

[15] Huber, W.C. (2005). EPA Storm Water Management Model, SWMM5. In: Huber, W.C., Rossman, L.A. and Dickinson, R.E., Watershed Models, 339.

[16] Rossman, L.A., Dickinson, R.E., Schade, T., Chan, C., Burgess, E.H., and Huber, W.C. (2005). SWMM5: The USEPA's newest tool for urban drainage analysis. Proceedings of 10th ICUD, Copenhagen, 1-8. ftp://152.66.121.2/Oktatas/Epito2000/KozmuhalozatokTervezese-SP2/swmm/epaswmm5_manual.pdf [Accessed 11rd August 2014].

[17] Jang, S., Cho, M., Yoon, J., Yoon, Y., Kim, S., Kim, G. and Aksoy, H. (2007). Using SWMM as a tool for hydrologic impact assessment. Desalination, 212(1), 344-356.

[18] United States Environmental Protection Agency. (2013). Storm Water Management Model (SWMM). Available from http://www.epa.gov/nrmrl/wswrd/wq/models/swmm/ [Accessed 11 th August 2014]. 


\section{Authors}

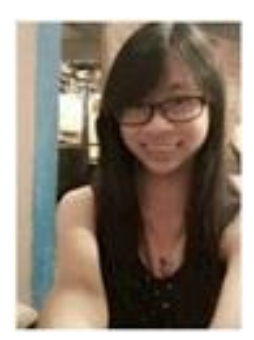

\section{Evon E.W. Tang}

Evon E.W. Tang is a graduate student, attached to the Department of Civil Engineering, Faculty of Engineering, Universiti Malaysia Sarawak (UNIMAS). She received her B.Eng. (Hons) in Civil Engineering in 2015.

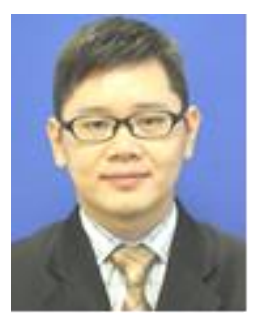

\section{Darrien Yau Seng Mah}

Darrien Y.S. Mah is a senior lecturer, attached to the Department of Civil Engineering, Faculty of Engineering, Universiti Malaysia Sarawak (UNIMAS). He received his $\mathrm{PhD}$ (Water Resources) in 2009. His field of interest is water resources modelling. 